\title{
Recent advances in understanding and management of
}

\section{bronchopulmonary dysplasia [version 1; peer review: 2}

\section{approved]}

\author{
Mitali Sahni(D)1,2, Vineet Bhandari(i)3 \\ ${ }_{1}^{1}$ Pediatrix Medical Group, Sunrise Children's Hospital, Las Vegas, NV, USA \\ 2University of Nevada, Las Vegas, NV, USA \\ ${ }^{3}$ Neonatology Research Laboratory, Education and Research Building, Cooper University Hospital, Camden, NJ, USA
}

V1 First published: 14 Jul 2020, 9(Faculty Rev):703

https://doi.org/10.12688/f1000research.25338.1

Latest published: 14 Jul 2020, 9(Faculty Rev):703

https://doi.org/10.12688/f1000research.25338.1

\section{Abstract}

In the current era, the survival of extremely low-birth-weight infants has increased considerably because of new advances in technology; however, these infants often develop chronic dysfunction of the lung, which is called bronchopulmonary dysplasia (BPD). BPD remains an important cause of neonatal mortality and morbidity despite newer and gentler modes of ventilation. BPD results from the exposure of immature lungs to various antenatal and postnatal factors that lead to an impairment in lung development and aberrant growth of lung parenchyma and vasculature. However, we still struggle with a uniform definition for BPD that can help predict various short- and long-term pulmonary outcomes. With new research, our understanding of the pathobiology of this disease has evolved, and many new mechanisms of lung injury and repair are now known. By utilizing the novel 'omic' approaches in BPD, we have now identified various factors in the disease process that may act as novel therapeutic targets in the future. New investigational agents being explored for the management and prevention of BPD include mesenchymal stem cell therapy and insulin-like growth factor 1 . Despite this, many questions remain unanswered and require further research to improve the outcomes of premature infants with BPD.

\section{Keywords}

Newborn, hyperoxia, chronic lung disease, premature

\section{Open Peer Review \\ Approval Status \\ 2 \\ version 1 \\ 14 Jul 2020 \\ Faculty Reviews are review articles written by the prestigious Members of Faculty Opinions. The articles are commissioned and peer reviewed before publication to ensure that the final, published version is comprehensive and accessible. The reviewers who approved the final version are listed with their names and affiliations.}

1. Cynthia T. McEvoy, Oregon Health \& Science University, Portland, USA

\section{Juan Sanchez-Esteban, Alpert Medical}

School of Brown University, Rhode Island, USA

Any comments on the article can be found at the end of the article. 
Corresponding author: Vineet Bhandari (Bhandari-vineet@cooperhealth.edu)

Author roles: Sahni M: Conceptualization, Writing - Original Draft Preparation, Writing - Review \& Editing; Bhandari V:

Conceptualization, Project Administration, Supervision, Writing - Review \& Editing

Competing interests: No competing interests were disclosed.

Grant information: The author(s) declared that no grants were involved in supporting this work.

Copyright: (c) 2020 Sahni $\mathrm{M}$ and Bhandari V. This is an open access article distributed under the terms of the Creative Commons Attribution License, which permits unrestricted use, distribution, and reproduction in any medium, provided the original work is properly cited.

How to cite this article: Sahni $\mathrm{M}$ and Bhandari V. Recent advances in understanding and management of bronchopulmonary dysplasia [version 1; peer review: 2 approved] F1000Research 2020, 9(Faculty Rev):703

https://doi.org/10.12688/f1000research.25338.1

First published: 14 Jul 2020, 9(Faculty Rev):703 https://doi.org/10.12688/f1000research.25338.1 


\section{Introduction}

Bronchopulmonary dysplasia (BPD) was described as a new lung disease in preterm infants with respiratory distress syndrome (RDS) by Northway et al., in $1967^{1}$. They described this syndrome in premature infants exposed to high supplemental oxygen and invasive mechanical ventilation who developed lung injury with specific airway histopathological features. BPD has evolved over the past five decades with the advent of new and effective perinatal strategies, including the use of antenatal steroids and surfactants, restricted use of oxygen, and a focus on the use of non-invasive, gentler modes of ventilation ${ }^{2}$. Despite this, BPD remains one of the most common complications associated with prematurity ${ }^{3}$. Newer BPD tends to have a milder initial clinical presentation of the illness compared to old BPD. A subgroup of infants with new BPD are ventilatordependent and develop severe disease as it moves from the early to evolving and established phases ${ }^{4,5}$. BPD continues to be a major cause of respiratory morbidities in the modern era as we push the limits of viability and see increased survival of extremely preterm infants born at 22-24 weeks of gestation ${ }^{6}$. In this review, we discuss the new advances in understanding the pathobiology of this disease, the current controversy regarding the definition of BPD, use of the novel "omic" approaches in BPD, and how this affects our assessment of this disease. We also discuss the current and upcoming therapies for the management of BPD and summarize the unanswered questions that require further research to improve the outcomes of premature infants with BPD.

\section{Epidemiology and pathophysiology}

Based on studies from various neonatal networks across many countries, including the United States, Canada, Korea, China, and India, the prevalence of BPD has been reported to be quite variable, ranging from 11 to $50 \%$, and can be attributed to differences in the criteria of diagnosis and management approaches ${ }^{7}$. The incidence of BPD increases with a decrease in gestational age (GA) and birth weight ${ }^{6}$. The other perinatal factors affecting it are male $\operatorname{sex}^{8}$, intrauterine growth restriction ${ }^{9}$, chorioamnionitis $^{10}$, smoking ${ }^{11}$, and race/ethnicity ${ }^{9}$. Postnatal factors also increase the risk for BPD and poor outcomes, including RDS at birth, requirement for invasive mechanical ventilation and supplemental oxygen, lung inflammation, pulmonary vascular disease, air leaks, infections, presence of hemodynamically significant patent ductus arteriosus, and nutritional deficiencies ${ }^{12}$.

A potential role for placental insufficiency in the development of BPD and BPD-associated pulmonary hypertension $(\mathrm{PH})$ has been proposed and investigated in recent years. Placenta-mediated complications in pregnancy are associated with moderate to severe BPD in very preterm infants. This was independent of GA and birth weight ${ }^{13}$. Fetal growth restriction can predispose to impaired lung development. Similarly, decreased placental villous vascularity was seen in BPD-associated $\mathrm{PH}^{14,15}$. These studies show that placental disturbances play a vital role in lung alveolarization and represent a novel and important area in lung developmental pathobiology ${ }^{16,17}$.
The microbiome is also emerging as an important factor in disease pathobiology, and studies have revealed differences in the airway microbiome of preterm and term infants and infants with BPD. Furthermore, longitudinal changes in the airway microbiome of preterm infants requiring invasive mechanical ventilation may be associated with severity of BPD, although it is yet to be determined if these changes are causal or a consequence of the management of these infants. Preterm infants $<34$ weeks GA and birth weight 500-1,250 g who eventually developed severe BPD demonstrated abundance of Ureaplasma and less Staphylococcus in their tracheal aspirates in the first few days after birth ${ }^{18,19}$. All of these studies attest to the potential contribution of the microbiome in the dysregulated development of the lungs ${ }^{20,21}$. Figure 1 summarizes the factors contributing to the pathobiology of new BPD.

\section{Diagnosis and assessment}

Does an ideal definition of bronchopulmonary dysplasia exist?

Various definitions exist for diagnosing BPD; however, most of them suffer from the primary limitation of utilizing a treatment modality as the primary factor defining the disease rather than the disease pathology or severity ${ }^{22}$. One of the commonly used definitions of BPD is the NIH consensus definition by Jobe et al., which recommends diagnosing infants with BPD based on their oxygen exposure and determines severity by assessing their respiratory support at 36 weeks postmenstrual age $(\mathrm{PMA})^{23}$. A major limitation of the available definitions of BPD is their inability to diagnose BPD in infants dying from severe respiratory failure before 36 weeks PMA. These infants comprise a subset of extremely preterm infants who are at high risk for developing severe BPD if they survive. An additional challenge comes from the increasing use of high-flow nasal cannula for oxygen therapy that provides a variable degree of positive end-expiratory pressure, thus creating the conundrum of whether these infants should be classified on the basis of supplemental oxygen concentration alone or by including the positive pressure that they receive. On the other end of the spectrum, we have infants on $100 \%$ oxygen via very low nasal cannula flows who may not be appropriately categorized with the available definitions. Another group of infants difficult to classify are those dependent on positive-pressure ventilation for airway abnormalities or abnormal respiratory control with no or minimal parenchymal lung disease. These infants should not be classified as having BPD, but we do not have the adequate means to re-categorize them currently ${ }^{24}$.

In the summary from the workshop on BPD organized by the Eunice Kennedy Shriver National Institute of Child Health and Human Development (NICHD), the expert panel proposed an updated definition of $\mathrm{BPD}^{25}$. In this new definition, the panel addresses the use of contemporary modes of ventilation and stage BPD based on the precise respiratory support and fraction of inspired oxygen $\left(\mathrm{FiO}_{2}\right)$ being used. They also exclude the need for supplemental $\mathrm{O}_{2}$ exposure for 28 days and include "radiographic confirmation of parenchymal disease" ${ }^{26}$. The use of 


\section{Factors contributing to the pathobiology of new bronchopulmonary dysplasia (BPD)}

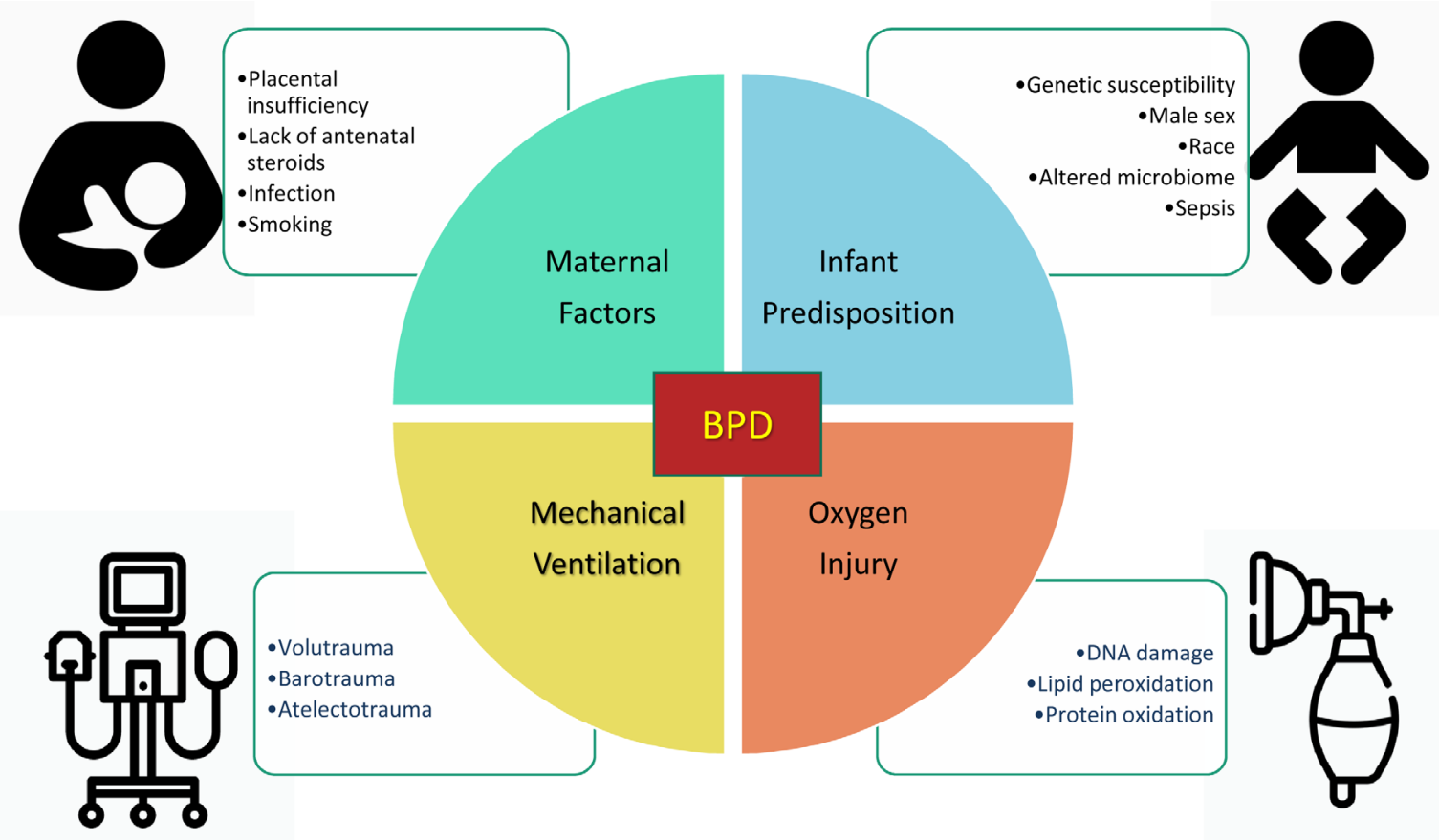

Figure 1. Factors contributing to the pathobiology of new bronchopulmonary dysplasia (BPD). Premature infants at risk owing to maternal and infant factors develop new BPD when exposed to invasive mechanical ventilation and hyperoxia.

this definition accurately predicted death or serious respiratory morbidity at $18-26$ months corrected age in $81 \%$ of infants in the study $^{27}$. An ideal definition of BPD should be objective, take into account the pathophysiology, and be able to predict meaningful long-term outcomes ${ }^{28,29}$. Use of long-term biomarkers for assessing lung injury ${ }^{30}$, imaging studies like functional magnetic resonance imaging to assess lung structure ${ }^{31}$, and novel ways to assess pulmonary function will be required to create a new classification system for BPD that is more centered on lung function evaluation and pathophysiology ${ }^{28}$.

\section{The "omics" in bronchopulmonary dysplasia}

In order to accurately assess the lung pathology in BPD, several traditional biomarkers have been utilized, but, owing to variable phenotypes seen in BPD, these biomarkers have low predictive value $^{30}$. In the past decade, newer technologies have allowed the detailed analysis of "big data sets" through bioinformatics to help in delineating the pathogenesis, mechanisms, and diagnosis of diseases. Novel systems biology-based "omic" approaches can be utilized to define the multiple cellular and humoral interactions that regulate the dysregulated lung development and injury response in BPD.

Metabolomics has been utilized to develop a panel of biomarkers to identify neonates at risk of developing BPD. Metabolomics consists of quantitative analysis of many low-molecular-mass metabolites found in a specific cell, organ, or organism involving substrates or products of a defined metabolic pathway. The changes in metabolite composition reflect the interaction among a genetic predisposition, a specific pathophysiological state, and environmental stimuli and can provide a unique fingerprint of those pathophysiological changes that predict the predisposition to the disease ${ }^{32}$. La Frano et al., studied the metabolomics in umbilical cord blood from 10 neonates who later developed BPD and compared them to 10 controls and found an alteration in lipid metabolism that may be responsible for an immaturity of lipid biosynthesis in these infants ${ }^{33}$. In another study evaluating tracheal aspirate fluid from 68 preterm neonates on the first day of life, the authors demonstrated that neonates who develop BPD later in life have higher levels of serine, alanine, taurine, and citrulline compared to neonates who do not develop BPD ${ }^{34}$.

As mentioned earlier in this review, various studies have demonstrated associations between dysbiosis of the airway microbiome and BPD; however, the direction of causality between airway injury during lung development and respiratory colonization with microorganisms is unclear. A systematic review of six studies investigating the airway microbiome of preterm infants showed that early microbiome contains Firmicutes and 
Proteobacteria as the predominant phyla and Staphylococcus and Ureaplasma as the predominant genera ${ }^{19}$. Infants who eventually developed severe BPD demonstrated an abundance of Ureaplasma and less Staphylococcus in their tracheal aspirates initially after birth ${ }^{18}$. BPD progression was associated with increased microbial community turnover, change in relative abundance of Firmicutes and Proteobacteria, and decrease in Lactobacilli $^{19,20}$. Metabolomics and microbiomics can be integrated to help guide us to the pathways that are activated in newborns who develop BPD based on the microbiome they have in their airways/lungs ${ }^{32}$. Lal et al. investigated this relationship between airway microbiome and metabolome at birth. They found that in infants with BPD, there is an increase in Proteobacteria, a reduction in Lactobacilli, and a decrease in the ratio of acetyl-CoA/propionyl-CoA carboxylase, indicating a curtailed fatty acid $\beta$-oxidation pathway. These changes suggest that the metabolic activity of the airway microbiome may in fact modulate the metabolome. The authors further postulated that the lipid metabolites from the bacteria may cause increased airway inflammation, leading to $\mathrm{BPD}^{35}$.

Proteomics is the large-scale study of the structure and function of proteins which may help evaluate the networks of proteins that can specify the real-time status of disease state and protein function modulation ${ }^{36}$. Analysis of bronchoalveolar lavage fluid in preterm babies using a proteomics-based approach showed that calcium signaling-related proteins differed with BPD severity ${ }^{37}$. In a study evaluating plasma proteins using proteomics in preterm infants, it was noted that there was decreased gelsolin, afamin, and carboxypeptidase $\mathrm{N}$ subunit 2 levels in cord blood ${ }^{38}$. In addition, there was decreased hemoglobin subunit gamma-1 and galectin-3 binding protein levels, along with increased serotransferrin in plasma at 36 weeks PMA $^{38}$. In a recent study by Förster et al., proteomic screening was utilized in plasma samples from preterm infants to identify novel biomarkers of BPD that could help in the early identification of such infants. They reported that increased levels of sialic acid-binding immunoglobulin-type lectin (SIGLEC)-14 and basal cell adhesion molecule (BCAM) along with decreased levels of angiopoietin-like 3 (ANGPTL3) in the first week of life can predict the outcome of BPD with high specificity and sensitivity $^{39}$.

In the field of genomics, various approaches including integrated genomic analysis ${ }^{40}$ and gene expression profiling ${ }^{41}$ have led to the identification of novel pathways of lung development and repair (the cell-surface glycoprotein CD44, phosphorus oxygen lyase activity) and novel molecules and pathways (adenosine deaminase, targets of microRNA [miR]) that are associated with the genetic origins of $\mathrm{BPD}^{42}$. In addition to whole exome sequencing and whole genome sequencing to identify non-common variants in patients with BPD, RNA sequencing methods have been developed to evaluate proteincoding mRNA, transcripts of pseudogenes, long non-coding RNA (lncRNA), and miRs ${ }^{43}$. In the last few years, miRs have been described as important mediators of normal growth, development, and disease. In a recent study, Syed et al. showed that miR-34a levels are significantly increased in the lungs of neonatal mice exposed to hyperoxia; deletion or inhibition of miR-34a improved the pulmonary phenotype and BPD-associated pulmonary arterial hypertension (PAH) in mouse models of $\mathrm{BPD}^{44}$. Pharmacologic inhibition of miR-34a can thus be used as a potential therapeutic option in neonates to prevent hyperoxiainduced lung injury ${ }^{45}$. In another study, increased expression of miR-451 was noted in animal models of BPD and inhibition of miR-451 was shown to improve the cardiopulmonary phenotype $^{46}$. Similarly, potential roles for miR-17 92 ${ }^{47}$, miR-29b ${ }^{48}$, miR-876-3 $p^{49}$, miR-199a-5 $p^{50}$, and miR- $489^{51}$ have been described in the pathogenesis of BPD.

\section{New and upcoming therapies in the management and prevention of bronchopulmonary dysplasia}

Despite the high prevalence of BPD, no new drugs have been approved for the management of this disease over the past two decades. To date, among the many tried interventions, postnatal use of vitamin $\mathrm{A}^{52,53}$, caffeine ${ }^{54}$, and corticosteroids ${ }^{55}$ are the only interventions that have led to a decrease in the rate of BPD. The use of vitamin $\mathrm{C}$ in pregnant smokers has been shown to improve pulmonary function tests in newborns at birth and 3 months of age with decreased wheezing up to 1 year of age $^{56,57}$. Since smoking is a significant risk factor for BPD, use of vitamin $\mathrm{C}$ in this population may help to mitigate the effects of smoking on the developing lung; however, no clinical trials have evaluated this potential therapy as yet specifically to decrease BPD. Systemic corticosteroids have been used for decades to decrease BPD, with dexamethasone being one of the initial therapies to have been adopted. Although dexamethasone clearly decreased the rate of BPD, it caused various shortand long-term adverse effects that have led to a decrease in its use over time ${ }^{58}$. Dexamethasone lacks mineralocorticoid activity and has been associated with serious neurodevelopmental impairment due to apoptosis in areas of the brain critical to learning and memory ${ }^{59}$. Over the past few years, hydrocortisone use has gained popularity in extremely premature infants either for the management of hemodynamic failure or for the prevention of $\mathrm{BPD}^{55}$. An individual patient data meta-analysis including almost 1,000 extremely preterm infants showed that early low-dose hydrocortisone therapy is beneficial for survival without BPD and without adverse effects on neurodevelopment at 2 years of age ${ }^{60}$. Data from two clinical trials have shown that in very low-birth-weight infants with severe RDS, intra-tracheal administration of surfactant/budesonide combination compared with surfactant alone significantly decreased the incidence of BPD or death ${ }^{61,62}$. Larger trials are underway to determine if this should be recommended as standard of care. Mesenchymal stem cell (MSC) therapy and insulin-like growth factor (IGF)-1 (in combination with IGF-binding protein 3 [IGFB3]) are the new investigational agents that are being explored currently to prevent BPD. Figure 2 denotes the new and emerging therapies for the management and prevention of BPD.

Stem cell-based therapies in bronchopulmonary dysplasia MSCs play a vital role in lung development, and the therapeutic use of MSCs to treat and prevent BPD has emerged as a promising field. In preclinical studies, exogenous stem cells protect and repair hyperoxia-induced lung injury and improve survival. 


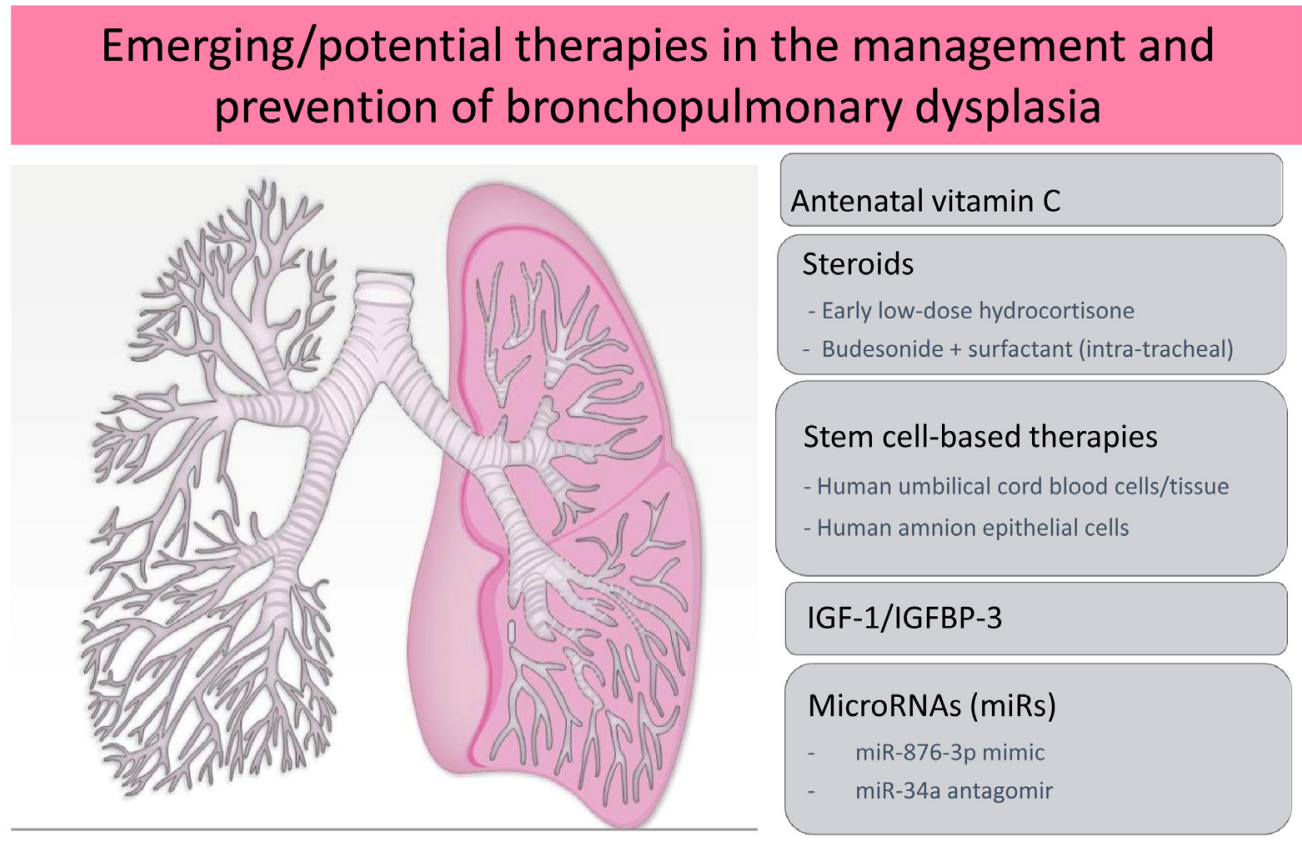

Figure 2. Emerging/potential therapies in the management and prevention of bronchopulmonary dysplasia. These include antenatal vitamin C, steroids, stem cell-based therapies, insulin-like growth factor-1 (IGF-1) in combination with IGF-binding protein-3 (IGFBP-3), and microRNAs.

The precise mechanism by which they act is not completely known; however, it is believed that MSCs act primarily via a paracrine effect $^{63}$. In a systematic review evaluating the various cell based therapies in preclinical BPD, MSCs were found to be the most efficacious among all interventions, although they were exclusively investigated in the rodent hyperoxia-exposed model of $\mathrm{BPD}^{64}$. Human umbilical cord tissue and cord blood have been identified as a potential source of MSCs and have been further explored as a feasible source of these cells and exosomes $^{65,66}$. At least two phase I clinical trials of human cord blood-derived MSCs have been successfully conducted in South Korea and the United States ${ }^{67,68}$. Another source for similar cells is from placental membranes, human amnion epithelial cells (hAECs), which have shown considerable promise in preclinical models of BPD. The first human clinical trial of hAECs in neonates with BPD has been completed to assess the safety of these cells ${ }^{69}$.

\section{Insulin-like growth factor-1}

IGF-1 is a significant regulator of lung angiogenesis, fetal growth, and development. Lower levels of IGF-1 have been independently associated with increased risk of BPD and retinopathy of prematurity. In neonatal rodent models of hyperoxiainduced lung injury, the administration of IGF-1 seems to reduce lung injury ${ }^{70}$. In a phase II clinical trial, treatment with recombinant human IGF along with its binding protein (rhIGF-1/ rhIGFBP-3) reduced the incidence of severe BPD as a secondary outcome $^{71}$.

\section{Summary}

Despite great advances in lung research and evolving management of BPD over the years, many questions remain unanswered and present unique opportunities for research. The pathobiology of BPD is a rapidly evolving field of research with potential for utilizing the newer "omic" approaches to better understand the molecular pathways and cell interactions specific to injury in BPD. The development of an appropriate BPD definition that is based on pathophysiology and can predict long-term pulmonary outcomes remains a top priority. This would also help as a useful and uniform clinical end point ${ }^{72}$. As we continue on our search for better biomarkers in BPD, further research should focus on clinical, imaging, and biological markers to better diagnose and manage these infants. Lastly, the advancement in cell-based therapies provides a novel opportunity to understand the biology of the repair cells and identify new targets in injury and repair pathways in BPD. Despite the severe lung injury in BPD, most infants achieve remarkable recovery of lung structure and function. Exploring the cause of this resilience of the neonatal lung will provide further insights into the pathogenesis of chronic lung diseases. 
1. Northway WH Jr, Rosan RC, Porter DY: Pulmonary disease following respirator therapy of hyaline-membrane disease. Bronchopulmonary dysplasia. $N$ Engl Med. 1967; 276(7): 357-68.

PubMed Abstract | Publisher Full Text

2. Dumpa V, Bhandari V: Surfactant, steroids and non-invasive ventilation in the prevention of BPD. Semin Perinatol. 2018; 42(7): 444-52. PubMed Abstract | Publisher Full Text

3. Nelin LD, Bhandari V: How to decrease bronchopulmonary dysplasia in your neonatal intensive care unit today and "tomorrow" [version 1; peer review: 2 approved]. F1000Res. 2017; 6(F1000 Faculty Rev): 539 PubMed Abstract | Publisher Full Text | Free Full Text

4. Bancalari E, Jain D: Bronchopulmonary Dysplasia: 50 Years after the Original Description. Neonatology. 2019; 115(4): 384-91. PubMed Abstract | Publisher Full Text | Faculty Opinions Recommendation

5. Bhandari A, Bhandari V: Pitfalls, Problems, and Progress in Bronchopulmonary Dysplasia. Pediatrics. 2009; 123(6): 1562-73. PubMed Abstract | Publisher Full Text

6. Stoll BJ, Hansen NI, Bell EF, et al:: Trends in Care Practices, Morbidity, and Mortality of Extremely Preterm Neonates, 1993-2012. JAMA. 2015; 314(10): 1039-51.

PubMed Abstract | Publisher Full Text | Free Full Text

7. Thébaud B, Goss KN, Laughon M, et al.: Bronchopulmonary dysplasia. Nat Rev Dis Primers. 2019; 5(1): 78.

PubMed Abstract | Publisher Full Text | Free Full Text

Faculty Opinions Recommendation

8. Leary S, Das P, Ponnalagu D, et al:: Genetic Strain and Sex Differences in a Hyperoxia-Induced Mouse Model of Varying Severity of Bronchopulmonary Dysplasia. Am J Pathol. 2019; 189(5): 999-1014. PubMed Abstract | Publisher Full Text | Free Full Text

9. Bose C, van Marter LJ, Laughon M, et al:: Fetal growth restriction and chronic lung disease among infants born before the $\mathbf{2 8}^{\text {th }}$ week of gestation. Pediatrics. 2009; 124(3): e450-8.

PubMed Abstract | Publisher Full Text | Free Full Text

10. Hartling L, Liang $\mathrm{Y}$, Lacaze-Masmonteil $\mathrm{T}$ : Chorioamnionitis as a risk factor for bronchopulmonary dysplasia: A systematic review and meta-analysis. Arch Dis Child Fetal Neonatal Ed. 2012; 97(1): F8-F17. PubMed Abstract | Publisher Full Text

11. Antonucci R, Contu P, Porcella A, et al: Intrauterine smoke exposure: A new risk factor for bronchopulmonary dysplasia? J Perinat Med. 2004; 32(3): 272-7. PubMed Abstract | Publisher Full Text

12. Kalikkot Thekkeveedu R, Guaman MC, Shivanna B: Bronchopulmonary dysplasia: A review of pathogenesis and pathophysiology. Respir Med. 2017; 132: $170-7$.

PubMed Abstract | Publisher Full Text | Free Full Text

13. Torchin H, Ancel PY, Goffinet F, et al:: Placental Complications and Bronchopulmonary Dysplasia: EPIPAGE-2 Cohort Study. Pediatrics. 2016; 137(3): e20152163.

PubMed Abstract | Publisher Full Text | Free Full Text

14. Yallapragada SG, Mestan KK, Palac H, et al:: Placental Villous Vascularity is Decreased in Premature Infants with Bronchopulmonary DysplasiaAssociated Pulmonary Hypertension. Pediatr Dev Pathol. 2016; 19(2): 101-7. PubMed Abstract | Publisher Full Tex

15. Bhandari $\mathrm{V}$, Lodha $\mathrm{A}$ : Is bronchopulmonary dysplasia decided before birth? Pediatr Res. 2020; 87(5): 809-10. PubMed Abstract | Publisher Full Text

16. Morrow LA, Wagner BD, Ingram DA, et al:: Antenatal Determinants of Bronchopulmonary Dysplasia and Late Respiratory Disease in Preterm Infants. Am J Respir Crit Care Med. 2017; 196(6): 364-74. PubMed Abstract | Publisher Full Text | Free Full Text

17. Taglauer E, Abman SH, Keller RL: Recent advances in antenatal factors predisposing to bronchopulmonary dysplasia. Semin Perinatol. 2018; 42(7): 413-24.

PubMed Abstract | Publisher Full Text | Free Full Text |

Faculty Opinions Recommendation

18. Wagner BD, Sontag MK, Harris JK, et al.: Airway Microbial Community Turnover Differs by BPD Severity in Ventilated Preterm Infants. PLoS One. 2017; 12(1): e0170120.

PubMed Abstract | Publisher Full Text | Free Full Text

19. Pammi M, Lal CV, Wagner BD, et al.: Airway Microbiome and Development of Bronchopulmonary Dysplasia in Preterm Infants: A Systematic Review. J Pediatr. 2019; 204: 126-133.e2. PubMed Abstract | Publisher Full Text

20. Lal CV, Travers C, Aghai ZH, et al.: The Airway Microbiome at Birth. Sci Rep. 2016; 6: 31023

PubMed Abstract | Publisher Full Text | Free Full Text

21. Surate Solaligue DE, Rodríguez-Castillo JA, Ahlbrecht K, et al.: Recent advances in our understanding of the mechanisms of late lung development and bronchopulmonary dysplasia. Am J Physiol Lung Cell Mol Physiol. 2017; 313(6):
L1101-L1153.

PubMed Abstract | Publisher Full Text

22. Ibrahim J, Bhandari V: The definition of bronchopulmonary dysplasia: An evolving dilemma. Pediatr Res. 2018; 84(5): 586-8.

PubMed Abstract | Publisher Full Text

23. Jobe AH, Bancalari E: Bronchopulmonary dysplasia. Am J Respir Crit Care Med. 2001; 163(7): 1723-9.

PubMed Abstract | Publisher Full Text

24. Jobe AH, Steinhorn R: Can We Define Bronchopulmonary Dysplasia? J Pediatr. 2017; 188: 19-23.

PubMed Abstract | Publisher Full Text

25. Higgins RD, Jobe AH, Koso-Thomas M, et al.: Bronchopulmonary Dysplasia: Executive Summary of a Workshop. J Pediatr. 2018; 197: 300-8. PubMed Abstract | Publisher Full Text | Free Full Text | Faculty Opinions Recommendation

26. Jensen EA, Wright CJ: Bronchopulmonary Dysplasia: The Ongoing Search for One Definition to Rule Them All. J Pediatr. 2018; 197: 8-10. PubMed Abstract | Publisher Full Text

27. Jensen EA, Dysart K, Gantz MG, et al.: The Diagnosis of Bronchopulmonary Dysplasia in Very Preterm Infants. An Evidence-based Approach. Am J Respir Crit Care Med. 2019; 200(6): 751-9.

PubMed Abstract | Publisher Full Text | Free Full Text | Faculty Opinions Recommendation

28. Bancalari E, Jain D: Bronchopulmonary Dysplasia: Can We Agree on a Definition? Am J Perinatol. 2018; 35(6): 537-40.

PubMed Abstract | Publisher Full Text | Faculty Opinions Recommendation

29. Sahni M, Mowes AK: Bronchopulmonary Dysplasia. StatPearls. Treasure Island (FL): StatPearls Publishing LLC.; 2019. PubMed Abstract

30. Bhandari A, Bhandari V: Biomarkers in bronchopulmonary dysplasia. Paediat Respir Rev. 2013; 14(3): 173-9. PubMed Abstract | Publisher Full Tex

31. D Förster K, Ertl-Wagner B, Ehrhardt H, et al:: Altered relaxation times in MR indicate bronchopulmonary dysplasia. Thorax. 2020; 75(2): 184-7. PubMed Abstract | Publisher Full Text | Faculty Opinions Recommendation

32. Piersigilli F, Bhandari V: Metabolomics of bronchopulmonary dysplasia. Clinica Chimica Acta. 2020; 500: 109-14 PubMed Abstract | Publisher Full Text

33. L La Frano MR, Fahrmann JF, Grapov D, et al:: Umbilical cord blood metabolomics reveal distinct signatures of dyslipidemia prior to bronchopulmonary dysplasia and pulmonary hypertension. Am J Physiol Lung Cell Mol Physiol. 2018; 315(5): L870-L881.

PubMed Abstract | Publisher Full Text | Free Full Text | Faculty Opinions Recommendation

34. Piersigilli $\mathrm{F}$, Lam TT, Vernocchi $\mathrm{P}$, et al:: Identification of new biomarkers of bronchopulmonary dysplasia using metabolomics. Metabolomics. 2019; 15(2)

PubMed Abstract | Publisher Full Text

35. Lal CV, Kandasamy J, Dolma K, et al.: Early airway microbial metagenomic and metabolomic signatures are associated with development of severe bronchopulmonary dysplasia. Am J Physiol Lung Cell Mol Physiol. 2018; 315(5): L810-L815.

PubMed Abstract | Publisher Full Text | Free Full Text

36. Piersigilli F, Bhandari V: Biomarkers in neonatology: The new "omics" of bronchopulmonary dysplasia. J Matern Fetal Neonatal Med. 2016; 29(11): 1758-64.

PubMed Abstract | Publisher Full Text

37. Magagnotti C, Matassa PG, Bachi A, et al.: Calcium signaling-related proteins are associated with broncho-pulmonary dysplasia progression. J Proteomics. 2013; 94: 401-12.

PubMed Abstract | Publisher Full Text

38. Zasada M, Suski M, Bokiniec R, et al:: Comparative two time-point proteome analysis of the plasma from preterm infants with and without bronchopulmonary dysplasia. Ital J Pediatr. 2019; 45(1): 112 PubMed Abstract | Publisher Full Text | Free Full Text | Faculty Opinions Recommendation

39. Förster K, Sass S, Ehrhardt H, et al.: Early Identification of Bronchopulmonary Dysplasia Using Novel Biomarkers by Proteomic Screening. Am J Respir Crit Care Med. 2018; 197(8): 1076-80. PubMed Abstract | Publisher Full Text | Faculty Opinions Recommendation

40. Ambalavanan N, Aschner JL: Management of hypoxemic respiratory failure and pulmonary hypertension in preterm infants. J Perinatol. 2016; 36 Suppl 2: S20-S27.

PubMed Abstract | Publisher Full Text

41. Pietrzyk JJ, Kwinta P, Wollen EJ, et al:: Gene expression profiling in preterm infants: New aspects of bronchopulmonary dysplasia development. PLOS One. 
2013; 8(10): e78585.

PubMed Abstract | Publisher Full Text | Free Full Text

42. Ambalavanan N, Cotten CM, Page GP, et al:: Integrated Genomic Analyses in Bronchopulmonary Dysplasia. J Pediatr. 2015; 166(3): 531-537.e13. PubMed Abstract | Publisher Full Text | Free Full Text

43. Lal CV, Bhandari V, Ambalavanan N: Genomics, microbiomics, proteomics, and metabolomics in bronchopulmonary dysplasia. Semin Perinatol. 2018; 42(7): 425-31.

PubMed Abstract | Publisher Full Text

44. Syed M, Das P, Pawar A, et al:: Hyperoxia causes miR-34a-mediated injury via angiopoietin-1 in neonatal lungs. Nat Commun. 2017; 8(1): 1173. PubMed Abstract | Publisher Full Text | Free Full Text

45. Das $P$, Syed MA, Shah $D$, et al.: miR34a: $A$ master regulator in the pathogenesis of bronchopulmonary dysplasia. Cell Stress. 2018; 2(2): 34-6. PubMed Abstract | Publisher Full Text | Free Full Text

46. Gilfillan M, Das $\mathrm{P}$, Shah D, et al:: Inhibition of microRNA-451 is associated with increased expression of Macrophage Migration Inhibitory Factor and mitgation of the cardio-pulmonary phenotype in a murine model of Bronchopulmonary Dysplasia. Respir Res. 2020; 21(1): 92. PubMed Abstract | Publisher Full Text | Free Full Text

47. Robbins ME, Dakhlallah D, Marsh CB, et al.: Of mice and men: Correlations between microRNA-17 92 cluster expression and promoter methylation in severe bronchopulmonary dysplasia. Am J Physiol Lung Cell Mol Physiol. 2016; 311(5): L981-L984.

PubMed Abstract | Publisher Full Text | Free Full Text

48. Durrani-Kolarik S, Pool CA, Gray A, et al:: miR-29b supplementation decreases expression of matrix proteins and improves alveolarization in mice exposed to maternal inflammation and neonatal hyperoxia. Am J Physiol Lung Cell Mol Physiol. 2017; 313(2): L339-L349.

PubMed Abstract | Publisher Full Text | Free Full Text

49. Lal CV, Olave N, Travers C, et al:: Exosomal microRNA predicts and protects against severe bronchopulmonary dysplasia in extremely premature infants. JCl Insight. 2018; 3(5): e93994.

PubMed Abstract | Publisher Full Text | Free Full Text

50. Alam MA, Betal SGN, Aghai ZH, et al:: Hyperoxia causes miR199a-5p-mediated injury in the developing lung. Pediatr Res. 2019; 86(5): 579-88. PubMed Abstract | Publisher Full Text

51. Olave N, Lal CV, Halloran B, et al:: Regulation of alveolar septation by microRNA-489. Am J Physiol Lung Cell Mol Physiol. 2016; 310(5): L476-87. PubMed Abstract | Publisher Full Text | Free Full Text

52. Tyson JE, Wright LL, Oh W, et al.: Vitamin A Supplementation for ExtremelyLow-Birth-Weight Infants. National Institute of Child Health and Human Development Neonatal Research Network. N Engl J Med. 1999; 340(25): 1962-8. PubMed Abstract | Publisher Full Text

53. Londhe VA, Nolen TL, Das A, et al:: Vitamin A supplementation in extremely low-birth-weight infants: Subgroup analysis in small-for-gestational-age infants. Am J Perinatol. 2013; 30(9): 771-80.

PubMed Abstract | Publisher Full Text | Free Full Text

54. Pakvasa MA, Saroha V, Patel RM: Optimizing Caffeine Use and Risk of Bronchopulmonary Dysplasia in Preterm Infants: A Systematic Review, Meta-analysis, and Application of Grading of Recommendations Assessment Development, and Evaluation Methodology. Clin Perinatol. 2018: 45(2): 273-91. PubMed Abstract | Publisher Full Text | Faculty Opinions Recommendation

55. Baud O, Watterberg KL: Prophylactic postnatal corticosteroids: Early hydrocortisone. Semin Fetal Neonatal Med. 2019; 24(3): 202-6. PubMed Abstract | Publisher Full Text | Faculty Opinions Recommendation

56. N McEvoy CT, Schilling D, Clay N, et al:: Vitamin C Supplementation for Pregnant Smoking Women and Pulmonary Function in Their Newborn Infants: A Randomized Clinical Trial. JAMA. 2014; 311(20): 2074-82. PubMed Abstract | Publisher Full Text | Free Full Text | Faculty Opinions Recommendation

57. N McEvoy CT, Shorey-Kendrick LE, Milner K, et al: Oral Vitamin C $(500 \mathrm{mg} / \mathrm{d})$ to Pregnant Smokers Improves Infant Airway Function at 3 Months (VCSIP). A Randomized Trial. Am J Respir Crit Care Med. 2019; 199(9): 1139-47. PubMed Abstract | Publisher Full Text | Free Full Text | Faculty Opinions Recommendation
58. Yoder BA, Harrison M, Clark RH: Time-Related Changes in Steroid Use and Bronchopulmonary Dysplasia in Preterm Infants. Pediatrics. 2009; 124(2): 673-9.

PubMed Abstract | Publisher Full Text

59. Crochemore C, Lu J, Wu Y, et al.: Direct targeting of hippocampal neurons for apoptosis by glucocorticoids is reversible by mineralocorticoid receptor activation. Mol Psychiatry. 2005; 10(8): 790-8. PubMed Abstract | Publisher Full Text

60. Shaffer ML, Baud O, Lacaze-Masmonteil T, et al.: Effect of Prophylaxis for Early Adrenal Insufficiency Using Low-Dose Hydrocortisone in Very Preterm Infants: An Individual Patient Data Meta-Analysis. J Pediatr. 2019; 207: 136-142.

PubMed Abstract | Publisher Full Text | Faculty Opinions Recommendation

61. Yeh TF, Lin HC, Chang $\mathrm{CH}$, et al.: Early intratracheal instillation of budesonide using surfactant as a vehicle to prevent chronic lung disease in preterm infants: A pilot study. Pediatrics. 2008; 121(5): e1310-8. PubMed Abstract | Publisher Full Text | Faculty Opinions Recommendation

62. Nyeh TF, Chen CM, Wu SY, et al.: Intratracheal Administration of Budesonide/Surfactant to Prevent Bronchopulmonary Dysplasia. Am J Respi Crit Care Med. 2016; 193(1): 86-95.

PubMed Abstract | Publisher Full Text | Faculty Opinions Recommendation

63. Strueby L, Thébaud B: Novel therapeutics for bronchopulmonary dysplasia. Curr Opin Pediatr. 2018; 30(3): 378-83.

PubMed Abstract | Publisher Full Text | Faculty Opinions Recommendation

64. Augustine S, Cheng W, Avey MT, et al.: Are all stem cells equal? Systematic review, evidence map and meta-analyses of preclinical stem cell-based therapies for bronchopulmonary dysplasia. Stem Cells Transl Med. 2019; 9(2): $158-68$.

PubMed Abstract | Publisher Full Text | Free Full Text |

Faculty Opinions Recommendation

65. Willis GR, Fernandez-Gonzalez A, Anastas J, et al.: Mesenchymal Stroma Cell Exosomes Ameliorate Experimental Bronchopulmonary Dysplasia and Restore Lung Function through Macrophage Immunomodulation. Am J Respir Crit Care Med. 2018; 197(1): 104-16.

PubMed Abstract | Publisher Full Text | Free Full Text | Faculty Opinions Recommendation

66. Chaubey S, Thueson S, Ponnalagu D, et al.: Early gestational mesenchymal stem cell secretome attenuates experimental bronchopulmonary dysplasia in part via exosome-associated factor TSG-6. Stem Cell Res Ther. 2018; 9(1): PubMed Abstract | Publisher Full Text | Free Full Text | Faculty Opinions Recommendation

67. Chang YS, Ahn SY, Yoo HS, et al:: Mesenchymal stem cells for : Phase 1 doseescalation clinical trial. $J$ Pediatr. 2014; 164(5): 966-972.e6. PubMed Abstract | Publisher Full Tex

68. Powell SB, Silvestri JM: Safety of Intratracheal Administration of Human Umbilical Cord Blood Derived Mesenchymal Stromal Cells in Extremely Low Birth Weight Preterm Infants. J Pediatr. 2019; 210: 209-213.e2. PubMed Abstract | Publisher Full Text | Faculty Opinions Recommendation

69. CLim R, Malhotra A, Tan J, et al.: First-In-Human Administration of Allogeneic Amnion Cells in Premature Infants With Bronchopulmonary Dysplasia: A Safety Study. Stem Cells Transl Med. 2018; 7(9): 628-35. PubMed Abstract | Publisher Full Text | Free Full Text | Faculty Opinions Recommendation

70. Mandell EW, Kratimenos P, Abman SH, et al.: Drugs for the Prevention and Treatment of Bronchopulmonary Dysplasia. Clin Perinatol. 2019; 46(2): 291-310. PubMed Abstract | Publisher Full Text

71. Ley D, Hallberg B, Hansen-Pupp I, et al:: rhIGF-1/rhIGFBP-3 in Preterm Infants: A Phase 2 Randomized Controlled Trial. J Pediatr. 2019; 206: 56-65.e8. PubMed Abstract | Publisher Full Text | Free Full Text | Faculty Opinions Recommendation

72. Steinhorn R, Davis JM, Göpel W, et al:: Chronic Pulmonary Insufficiency of Prematurity: Developing Optimal Endpoints for Drug Development. J Pediatr. 2017; 191: 15-21.e1.

PubMed Abstract | Publisher Full Text 


\section{Open Peer Review}

\section{Current Peer Review Status:}

\section{Editorial Note on the Review Process}

Faculty Reviews are review articles written by the prestigious Members of Faculty Opinions. The articles are commissioned and peer reviewed before publication to ensure that the final, published version is comprehensive and accessible. The reviewers who approved the final version are listed with their names and affiliations.

\section{The reviewers who approved this article are:}

\section{Version 1}

\section{Juan Sanchez-Esteban}

Department of Pediatrics, Alpert Medical School of Brown University, Rhode Island, USA

Competing Interests: No competing interests were disclosed.

\section{Cynthia T. McEvoy}

Division of Neonatology, Department of Pediatrics, Oregon Health \& Science University, Portland, USA

Competing Interests: No competing interests were disclosed.

The benefits of publishing with F1000Research:

- Your article is published within days, with no editorial bias

- You can publish traditional articles, null/negative results, case reports, data notes and more

- The peer review process is transparent and collaborative

- Your article is indexed in PubMed after passing peer review

- Dedicated customer support at every stage

For pre-submission enquiries, contact research@f1000.com 